Jurnal Riset Agama

Volume 1, Nomor 2 (Agustus 2021): 458-469

DOI: $10.15575 /$ jra.v1i2.14763

https://journal.uinsgd.ac.id/index.php/jra

\title{
Keutamaan Air Wudu sebagai Kecantikan Wajah: Studi Takhrij dan Syarah Hadis
}

\author{
Zhafirah Najla \\ Jurusan Ilmu Al-Qur'an dan Tafsir, Fakultas Ushuluddin \\ UIN Sunan Gunung Djati Bandung \\ najlazhafirah04@gmail.com
}

\begin{abstract}
This study aims to discuss the hadith regarding the virtues of ablution water as facial beauty through the application of takhrij and syarah hadith studies. This research method uses a qualitative approach through literature study related to contemporary analysis. The results of this study found that the hadith about the virtue of ablution as facial beauty is authentic in terms of sanad and matan. The discussion of this research is that on the Day of Resurrection, the people of the Prophet Muhammad. will be presented with a radiant face because of the remnants of the ablution water. The conclusion of this study is that cleanliness, chastity, and beauty can be maintained by carrying out ablution seriously without having to bother looking for and buying the right beauty products for the face. This research is expected to provide special benefits for women in the contemporary era.
\end{abstract}

Keywords: Beauty; Hadith; Wudu.

\begin{abstract}
Abstrak
Penelitian ini bertujuan membahas hadis mengenai keutamaan air wudu sebagai kecantikan wajah melalui pengaplikasian studi takhrij dan syarah hadis. Metode penelitian ini menggunakan pendekatan kualitatif melalui studi pustaka berkaitan dengan analisis kontemporer. Hasil penelitian ini menemukan bahwa hadis tentang keutamaan wudu sebagai kecantikan wajah ini bernilai shahih dari segi sanad dan matan. Pembahasan penelitian ini bahwa pada hari kiamat nanti umat Rasulullah Saw. akan dihadirkan dengan wajah yang berseriseri karena sisa dari air wudu. Kesimpulan penelitian ini adalah kebersihan, kesucian, dan kecantikan dapat terjaga dengan melaksanakan wudu sungguh-sungguh tanpa harus bersusah payah lagi mencari dan membeli produk kecantikan yang tepat
\end{abstract}


Jurnal Riset Agama, Volume 1, Nomor 2 (Agustus 2021): 458-469

Zhafirah Najla/Keutamaan Air Wudu sebagai Kecantikan Wajah: Studi Takhrij dan Syarah Hadis

bagi wajah. Penelitian ini diharapkan dapat memberikan manfaat terkhusus bagi kaum perempuan di era kontemporer.

Kata Kunci: Hadis; Kecantikan; Wudu.

\section{Pendahuluan}

Bersih atau sucinya seseorang secara lahir dan batin itu merupakan ciri terpenting dalam Islam (Zulfa, 2019). Bersuci salah satunya dapat dilakukan dengan berwudu. Kata al-wudhu'u diambil dari kata al-wadha'ah yang berarti cahaya kecantikan yang terpancar pada wajah seseorang atau kelompok sehingga membuat orang yang memandangnya merasa takjub dan kagum (Hidayati, 2008). Berwudu merupakan salah satu hal ihwal yang biasanya dilakukan sebelum melaksanakan ibadah salat. Banyak ulama yang tidak membatasi wudu hanya untuk melaksanakan salat, tetapi dapat dilakukan untuk tujuan lain (Syahputra, 2020). Wudu dilakukan dengan membasuh beberapa anggota tubuh yang merupakan anggota wudu dengan menggunakan air yang suci. Anggota wudu itu berada pada bagian luar dari tubuh yang kemungkinan besar terkena debu dan kotoran (Asmidar, 2018). Maka dari itu, kita dianjurkan untuk berwudu, karena manfaatnya sangat besar yang berpengaruh pada tubuh kita. Selain sebagai syarat untuk membersihkan diri sebelum ibadah, wudu juga bermanfaat untuk merawat kulit dan kecantikan wajah. Ini terjadi karena ketika air mengenai kulit, kotoran-kotoran yang menempel pada wajah akan berjatuhan, kulit yang terlihat kering akan menjadi lembab dan peredaran darah menjadi lancar. Menurut para pakar kulit dan kecantikan, faktor ini merupakan unsur-unsur yang sangat membantu seseorang untuk mencegah terjadinya penuaan dini (Zulfa, 2019). Namun, banyak kalangan masyarakat yang lebih memilih untuk membeli produk-produk kecantikan untuk kulit wajahnya. Bahkan, saat ini tren gaya hidup dan identitas seseorang dalam berpenampilan itu tergantung pada pemanfaatan produk kosmetik (Wiharsari, 2019). Padahal cukup dengan menjaga wudu setiap waktu dan melakukannya dengan benar, wudu itu dapat memancarkan cahaya kecantikan tersendiri dari wajah dan cahaya kecantikannya lebih alami serta bertahan lama.

Penulis lainnya telah melakukan penelitian berkenaan dengan keutamaan wudu, yaitu sebagaimana tercantum dalam tinjauan pustaka ini. Lela, \& Lukmawati (2015), "Ketenangan: Makna Dawamul Wudu (Studi Fenomena pada Mahasiswa UIN Raden Fatah Palembang)," Jurnal Psikologi Islami. Penelitian ini menggunakan pendekatan kualitatif fenomenologi. Kesimpulan dalam artikel ini yaitu bahwa dengan berwudu yang sesuai dengan ajaran Rasulullah Saw. dan melakukannya dengan sungguh-sungguh serta memiliki motivasi dalam diri untuk mempertahankan dawamul wudu dapat mengatasi berbagai hambatan dan 
Jurnal Riset Agama, Volume 1, Nomor 2 (Agustus 2021): 458-469

Zhafirah Najla/Keutamaan Air Wudu sebagai Kecantikan Wajah: Studi Takhrij dan Syarah Hadis

tantangan. Mahasiswa UIN Raden Fatah yang berhasil menjalani dawamul wudu selama lebih dari dua tahun dapat merasakan manfaat wudu bagi fisik, psikis, dan dapat menyentuh sisi ruhiyahnya. Dengan dawamul wudu perasaan menjadi nyaman, tentram, dan bahagia karena terhindar dari segala hal yang negatif, amarah berlebihan, perasaan gundah, dan sikap tergesa-gesa (Lela, 2015). Zulfa, F. F. (2019), “Manfaat Wudu terhadap Kesehatan dari Perspektif Hadis Nabi Saw. (Suatu Kajian Hadis Tahlili)," Universitas Islam Negeri Alauddin Makassar. Penelitian ini menggunakan pendekatan kualitatif. Dalam penelitian ini membahas pemahaman ulama hadis tentang manfaat wudu dari segi kesehatan yaitu dapat memadamkan api kemarahan, menjaga kebugaran dan kesegaran tubuh, menjaga kebersihan hidung, mulut, dan gigi, mencegah penuaan dini, menjernihkan hati, dan menjadikan hidup tetap semangat. Sedangkan menurut pemahaman ahli kesehatan, wudu bermanfaat untuk meningkatkan fungsi sistem peredaran darah pada bagian tubuh yang dibersihkan dan melancarkan penyaluran energi pada bagian tubuh yang dapat menjaga kekebalan tubuh (Zulfa, 2019). Syahputra, H. (2020), "Ritual Wudu: Upaya Menjaga Kesehatan Tubuh dengan Perawatan Spiritual," Jurnal Theosofi dan Peradaban Islam. Penelitian ini membahas tentang wudu bukan hanya untuk membersihkan kotoran lahiriah, tetapi juga mampu menghilangkan kotoran-kotoran batiniah. Berwudu secara lahiriah akan memunculkan kebersihan fisik, terutama terhadap anggotaanggota tubuh yang terkena basuhan air wudu. Sedangkan pada bagian anggota tubuh yang secara langsung tidak terkena basuhan air wudu, maka dapat dilakukan dengan batiniah. Dengan wudu secara batiniah akan mendatangkan kedamaian dan kesejukan di hati, karena merasakan dosa-dosanya diampuni oleh Allah Swt. (Syahputra, 2020).

Penelitian sebelumnya terkait keutamaan air wudu yang telah diuraikan di atas sangat bermanfaat pada penyusunan kerangka berpikir ini. Dalam penelitian ini penulis akan membahas keutamaan air wudu sebagai kecantikan. Setiap perempuan terlahir dengan kecantikan yang dimilikinya masing-masing. Menjadi cantik adalah impian hampir seluruh perempuan di dunia. Mereka bahkan rela melakukan apapun agar bisa terlihat lebih keren dan menawan. Penampilan rapi dan menawan pasti menjadi hal sangat penting bagi seorang perempuan, tak terkecuali muslimah yang harus sesuai syariat (Asmidar, 2018). Kecantikan dapat terpancar jika ada niat dan kemauan dalam diri perempuan untuk merutinkan melakukan perawatan kulit wajah. Cantik itu persoalan selera masing-masing individu yang sifatnya tidak bisa dipaksakan. Konsep kecantikan sendiri biasanya diidentikkan dengan sesuatu yang dianggap indah dan menarik untuk dipandang (Wiharsari, 2019). Islam tidak melarang perempuan yang ingin mempercantik diri, bahkan itu sudah menjadi ciri khas bagi kaum perempuan (Umbarani \& Fakhruddin, 2021). 
Jurnal Riset Agama, Volume 1, Nomor 2 (Agustus 2021): 458-469

Zhafirah Najla/Keutamaan Air Wudu sebagai Kecantikan Wajah: Studi Takhrij dan Syarah Hadis

Berbicara cantik, wudu dapat membuat kulit wajah putih bersinar serta terlihat keindahannya secara alami tanpa harus menghabiskan banyak uang untuk membeli produk-produk kecantikan. Wudu merupakan kegiatan berupa membasuh anggota tubuh yaitu wajah, kedua tangan, kepala, dan kedua kaki menggunakan air yang suci dan mensucikan sesuai syariat yang telah ditentukan (Zulfa, 2019). Wudu yaitu bersih, maka salah satu hakikatnya bertujuan untuk merawat kebersihan (Syahputra, 2020). Orang yang mengerjakan wudu dengan baik, maka akan memperoleh banyak manfaat (Afif, Muhammad \& Khasanah, 2018). Wudu menjadikan seseorang tampak lebih muda karena air wudu yang membasuh wajah akan meremajakan sel-sel kulit wajah dan membantu mencegah penuaan dini (Lela, 2015). Penelitian ini akan membahas keutamaan air wudu sebagai kecantikan wajah menggunakan takhrij dan syarah hadis. Sesuatu yang disandarkan kepada Nabi Saw. baik berupa ucapan, perbuatan, atau ketetapan yang dijadikan sebagai dalil hukum syar' $i$, baik sebelum kenabian atau sesudahnya itu merupakan pengertian dari hadis (Zulfa, 2019). Sedangkan takhrij adalah penelitian kualitas hadis dengan cara menelusuri atau mencari hadis dari berbagai sumber aslinya untuk diungkapkan matan serta sanadnya secara lengkap (Qomarullah, 2016). Syarah merupakan penjelasan atau pengungkapan makna yang terdapat pada suatu hadis (Muhtador, 2016).

Formula penelitian yang dapat disusun berdasarkan pada pemaparan di atas yaitu rumusan masalah penelitian, pertanyaan utama penelitian, dan tujuan penelitian (Darmalaksana, 2020a). Rumusan masalah penelitian ini adalah terdapat syarah hadis tentang keutamaan air wudu sebagai kecantikan wajah. Pertanyaan utama penelitian ini adalah bagaimana syarah hadis tentang keutamaan air wudu sebagai kecantikan wajah. Sedangkan pertanyaan penelitian secara terperinci yaitu bagaimana teks hadis tentang keutamaan wudu, bagaimana kualitas hadis tentang keutamaan wudu, dan bagaimana syarah hadis tentang keutamaan air wudu sebagai kecantikan wajah. Tujuan penelitian ini yaitu membahas syarah hadis tentang keutamaan air wudu sebagai kecantikan wajah. Penelitian ini diharapkan dapat memberi manfaat kepada masyarakat mengenai keutamaan air wudu sebagai kecantikan wajah.

\section{Metode Penelitian}

Metode penelitian ini menggunakan jenis pendekatan kualitatif melalui studi pustaka (Darmalaksana, 2020b). Penelitian ini menerapkan metode takhrij dan syarah hadis (Darmalaksana, 2020d) pada hadis yang berkenaan dengan keutamaan wudu melalui analisis kontemporer (Darmalaksana, 2020c). 
Jurnal Riset Agama, Volume 1, Nomor 2 (Agustus 2021): 458-469

Zhafirah Najla/Keutamaan Air Wudu sebagai Kecantikan Wajah: Studi Takhrij dan Syarah Hadis

\section{Hasil dan Pembahasan Penelitian}

Berikut ini hasil penelitian dan pembahasan.

\section{Teks Hadis Keutamaan Wudu}

Berdasarkan pencarian hadis tentang keutamaan wudu melalui aplikasi Ensiklopedia Hadis Kitab 9 Imam (Saltanera, 2015), terdapat beberapa hadis yang terkait, akan tetapi hadis yang akan menjadi pembahasan utama dalam penelitian ini adalah hadis riwayat Bukhari No. 133 Kitab Wudu Bab Keutamaan Wudu dan Putih Bersinar karena Bekas Wudu, sebagai berikut.

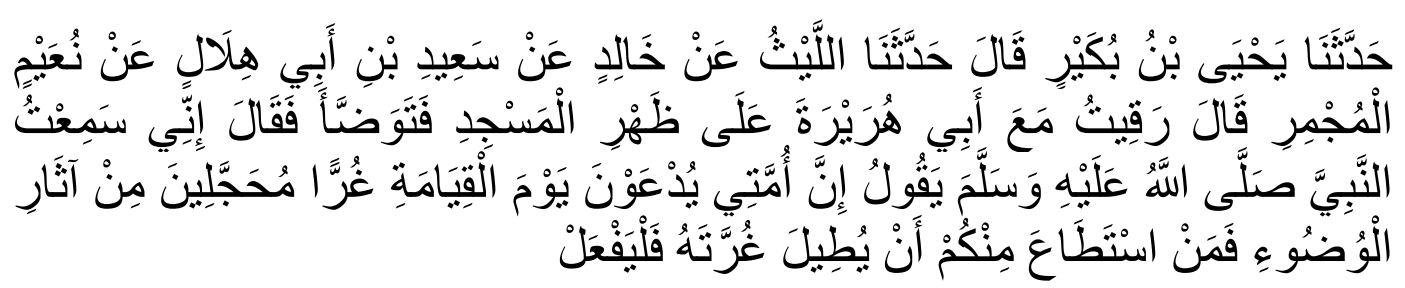

Artinya: Telah menceritakan kepada kami Yahya bin Bukair berkata, telah menceritakan kepada kami al-Laits dari Khalid dari Sa'id bin Abu Hilal dari Nu'aim bin al-Mujmir berkata, "Aku mendaki masjid bersama Abu Hurairah, lalu dia berwudu dan berkata, "Aku mendengar Nabi Saw. bersabda, "Sesungguhnya umatku akan dihadirkan pada hari kiamat dengan wajah berseri-seri karena sisa air wudu, maka barangsiapa diantara kalian yang mampu memanjangkan cahaya wajahnya maka lakukanlah" (HR. Bukhari).

\section{Takhrij Hadis Keutamaan Wudu}

Berikut ditampilkan tabel 1 daftar rawi dan sanad hadis riwayat Imam al-Bukhari No. 133.

Tabel 1. Daftar Rawi Sanad

\begin{tabular}{|c|c|c|c|c|c|c|c|}
\hline \multirow[t]{2}{*}{ No. } & \multirow{2}{*}{$\begin{array}{l}\text { Rawi } \\
\text { Sanad }\end{array}$} & & & Negeri & \multirow[t]{2}{*}{ Kuniyah } & Komentar Ulama & \multirow{2}{*}{ Kalangar } \\
\hline & & $\mathbf{L}$ & $\mathbf{W}$ & & & + & \\
\hline 1 & $\begin{array}{l}\text { Abdur } \\
\text { Rahman } \\
\text { bin Shakhr }\end{array}$ & & $\begin{array}{l}57 \\
\mathrm{H}\end{array}$ & Madinah & $\begin{array}{l}\text { Abu } \\
\text { Hurairah }\end{array}$ & $\begin{array}{l}\text { Ibnu Hajar } \\
\text { al-'Asqalani: } \\
\text { Shahabat }\end{array}$ & Shahabat \\
\hline 2 & $\begin{array}{l}\text { Nu'aim bin } \\
\text { 'Abdullah }\end{array}$ & & & Madinah & $\begin{array}{l}\text { Abu } \\
\text { ‘Abdullah }\end{array}$ & $\begin{array}{l}\text { Yahya bin } \\
\text { Ma'in: } \\
\text { Tsiqah; Abu } \\
\text { Hatim: } \\
\text { Tsiqah; An- }\end{array}$ & \\
\hline
\end{tabular}


Jurnal Riset Agama, Volume 1, Nomor 2 (Agustus 2021): 458-469

Zhafirah Najla/Keutamaan Air Wudu sebagai Kecantikan Wajah: Studi Takhrij dan Syarah Hadis

\begin{tabular}{|c|c|c|c|c|c|c|}
\hline & & & & & $\begin{array}{l}\text { Nasa'i: } \\
\text { Tsiqah; Ibnu } \\
\text { Sa'd: Tsiqah; } \\
\text { Ibnu Hibban: } \\
\text { Disebutkan } \\
\text { dalam 'ats } \\
\text { tsiqaat; Ibnu } \\
\text { Hajar Al- } \\
\text { 'Asqalani: } \\
\text { Tsiqah; Adz- } \\
\text { Dzahabi: } \\
\text { Tsiqah }\end{array}$ & $\begin{array}{l}\text { Tabi'in } \\
\text { kalangan } \\
\text { pertengahan }\end{array}$ \\
\hline 3 & $\begin{array}{l}\text { Sa'id bin } \\
\text { Abi Hilal }\end{array}$ & $\begin{array}{c}135 \\
-\quad \mathrm{H}\end{array}$ & Maru & $\begin{array}{l}\text { Abu Al- } \\
\text { 'Alaa' }\end{array}$ & $\begin{array}{l}\text { Ibnu Hibban: } \\
\text { Disebutkan } \\
\text { dalam 'ats } \\
\text { tsiqaat; Abu } \\
\text { Hatim: La ba' } \\
\text { sa bih; Ibnu } \\
\text { Hazm: Laisa } \\
\text { bi qawi; Ibnu } \\
\text { Sa'd: Tsiqah; } \\
\text { Al-'Ajli: } \\
\text { Tsiqah; Ibnu } \\
\text { Khuzaimah: } \\
\text { Tsiqah; Ad- } \\
\text { Daruquthni: } \\
\text { 'Adl; As- } \\
\text { Saaji: } \\
\text { Shaduuq; } \\
\text { Ibnu Hajar } \\
\text { al-'Asqalani: } \\
\text { Shaduuq }\end{array}$ & $\begin{array}{l}\text { Tabi'in (tidak } \\
\text { jumpa } \\
\text { Shahabat) }\end{array}$ \\
\hline 4 & $\begin{array}{l}\text { Khalid bin } \\
\text { Yazid }\end{array}$ & $\begin{array}{c}139 \\
\mathrm{H}\end{array}$ & Maru & $\begin{array}{l}\text { Abu } \\
\text { 'Abdur } \\
\text { Rahman }\end{array}$ & $\begin{array}{l}\text { An-Nasa'i: } \\
\text { Tsiqah; Abu } \\
\text { Zur'ah: } \\
\text { Tsiqah; Abu } \\
\text { Hatim: La ba' } \\
\text { sa bih; Ibnu } \\
\text { Hibban: } \\
\text { Disebutkan } \\
\text { dalam 'ats } \\
\text { tsiqaat; Al- } \\
\text { 'Ajli: Tsiqah; } \\
\text { Ya'qub bin } \\
\text { Sufyan: } \\
\text { Mishry }\end{array}$ & $\begin{array}{l}\text { Tabi'in (tidak } \\
\text { jumpa } \\
\text { Shahabat) }\end{array}$ \\
\hline
\end{tabular}


Jurnal Riset Agama, Volume 1, Nomor 2 (Agustus 2021): 458-469

Zhafirah Najla/Keutamaan Air Wudu sebagai Kecantikan Wajah: Studi Takhrij dan Syarah Hadis

\begin{tabular}{|c|c|c|c|c|c|c|c|c|}
\hline & & & & & & & $\begin{array}{l}\text { Tsiqah; Ibnu } \\
\text { Hajar al- } \\
\text { 'Asqalani: } \\
\text { Tsiqah Fakih; } \\
\text { Adz- } \\
\text { Dzahabi: } \\
\text { Faqih Tsiqah }\end{array}$ & \\
\hline 5 & $\begin{array}{l}\text { Laits bin } \\
\text { Sa'ad bin } \\
\text { 'Abdur } \\
\text { Rahman }\end{array}$ & & $\begin{array}{c}175 \\
\mathrm{H}\end{array}$ & Maru & $\begin{array}{l}\text { Abu Al- } \\
\text { Harits }\end{array}$ & & $\begin{array}{l}\text { Yahya bin } \\
\text { Ma'in: } \\
\text { Tsiqah; } \\
\text { Ahmad bin } \\
\text { Hambal: } \\
\text { Tsiqah; Abu } \\
\text { Zur'ah: } \\
\text { Tsiqah; } \\
\text { Muhammad } \\
\text { bin Sa'ad: } \\
\text { Tsiqah; Ibnu } \\
\text { Madini: } \\
\text { Tsiqah Tsabat }\end{array}$ & $\begin{array}{l}\text { Tabi'ut } \\
\text { Tabi'in } \\
\text { kalangan tua }\end{array}$ \\
\hline 6 & $\begin{array}{l}\text { Yahya bin } \\
\text { 'Abdullah } \\
\text { bin Bukair }\end{array}$ & & $\begin{array}{c}231 \\
\mathrm{H}\end{array}$ & Maru & $\begin{array}{l}\text { Abu } \\
\text { Zakariya }\end{array}$ & $\begin{array}{l}\text { An- } \\
\text { Nasa'i: } \\
\text { Dha'if }\end{array}$ & $\begin{array}{l}\text { Ibnu Hibban: } \\
\text { Disebutkan } \\
\text { dalam 'ats } \\
\text { tsiqaat; As } \\
\text { Saji: Shaduuq; } \\
\text { Al-Khalili: } \\
\text { Tsiqah; Ibnu } \\
\text { Qani': Tsiqah; } \\
\text { Ibnu Hajar } \\
\text { al-'Asqalani: } \\
\text { Tsiqah; Adz- } \\
\text { Dzahabi: } \\
\text { Hafizh }\end{array}$ & $\begin{array}{l}\text { Tabi'ul Atba' } \\
\text { kalangan tua }\end{array}$ \\
\hline 7 & $\begin{array}{l}\text { Abu } \\
\text { Abdillah } \\
\text { Muhammad } \\
\text { bin Ismail } \\
\text { bin Ibrahim } \\
\text { bin al- } \\
\text { Mughirah } \\
\text { bin } \\
\text { Bardizbah } \\
\text { al-Ju'fi al- } \\
\text { Bukhari }\end{array}$ & $\begin{array}{c}194 \\
\mathrm{H}\end{array}$ & $\begin{array}{c}256 \\
\mathrm{H}\end{array}$ & Bukhara & $\begin{array}{l}\text { Abu } \\
\text { Abdullah }\end{array}$ & & Imam Hadis & Mudawwin \\
\hline
\end{tabular}


Jurnal Riset Agama, Volume 1, Nomor 2 (Agustus 2021): 458-469

Zhafirah Najla/Keutamaan Air Wudu sebagai Kecantikan Wajah: Studi Takhrij dan Syarah Hadis

Tabel 1 merupakan daftar rawi dan sanad hadis riwayat Imam alBukhari No. 133 Kitab Wudu Bab Keutamaan Wudu dan Putih Bersinar karena Bekas Wudu. Pada tabel tersebut terdapat matrik rawi-sanad, tahun lahir dan wafat, negeri, kuniyah (panggilan), komentar ulama, dan disebutkan pula kalangannya. Hadis ini diriwayatkan oleh 7 (tujuh) orang rawi mulai dari mukharrij sampai mudawwin. Menurut ilmu hadis, rawi terakhir adalah sanad pertama sedangkan rawi pertama ialah sanad terakhir (Darmalaksana, 2021). Hanya 1 (satu) orang rawi yang tidak diketahui tahun lahir dan wafat, yaitu Nu'aim bin 'Abdullah. Semua ulama memberikan komentar positif kecuali penilaian negatif terhadap Yahya bin 'Abdullah bin Bukair yakni disebut dha'if oleh an-Nasa'i (Saltanera, 2015).

\section{Kualitas Hadis Keutamaan Air Wudu}

Keshahihan hadis dilihat dari rawinya yang adil dan kuat hafalannya (dhabit), sanadnya bersambung (muttasil), matan hadis tidak janggal (syadz), serta matan hadis tidak cacat (illat) (Darmalaksana, 2018). Pada tabel 1 tampak an-Nasa'i memberikan komentar dha' if pada seorang rawi yaitu Yahya bin 'Abdullah bin Bukair. Tetapi beberapa ulama lain menilai rawi tersebut tsiqah, shaduuq, dan ada juga yang menilainya hafizh. Sedangkan periwayat yang lain, kebanyakan ulama menilainya dengan komentar positif seperti tsiqah. Tsiqah adalah gabungan dari sifat adil dan dhabith, yang mana adil itu merupakan suatu sifat dalam jiwa seseorang yang dapat menghadapkan kepada perbuatan takwa dan menjaga kehormatan diri, sedangkan dhabith yaitu sikap tidak lalai yang berupa kuatnya hafalan (Nadhiran, 2014). Para ulama juga memberikan komentar positif selain tsiqah seperti disebutkan dalam 'ats tsiqaat, tsiqah tsabat, mishry tsiqah, tsiqah fakih, la ba' sa bih, laisa bi qawi, hafizh, shahabat, dan shaduuq.

Setelah dilakukan pencarian, hadis ini ternyata dikuatkan juga oleh hadis lain yakni hadis riwayat Imam Muslim No 363 yang seluruh periwayatnya tidak terdapat komentar negatif dari para ulama (Saltanera, 2015). Jadi walaupun terdapat satu rawi yang dinilai negatif pada hadis Imam Bukhari, komentar itu dapat ditutupi dengan $i^{\prime} t i b a r$, yaitu naiknya derajat hadis melalui syahid dan muttabi' (Darmalaksana, 2018). Pada hadis ini terdapat rawi yang tahun lahir dan wafatnya tidak diketahui. Maka dapat diperkirakan bahwa usia rawi lebih kurang 90 tahun (Darmalaksana, 2018). Untuk menunjukkan sanad bersambung metode yang digunakan Imam al-Bukhari yaitu apabila murid dengan guru atau periwayat kedua dengan periwayat pertama benar-benar bertemu, meskipun hanya sekali (Marzuki, 2006). Maka dapat dikatakan bahwa sanad hadis ini bersambung. Dari segi matan hadis, juga tidak ditemukan 
Jurnal Riset Agama, Volume 1, Nomor 2 (Agustus 2021): 458-469

Zhafirah Najla/Keutamaan Air Wudu sebagai Kecantikan Wajah: Studi Takhrij dan Syarah Hadis

adanya cacat dan janggal. Maka menurut Ijma' Ulama hadis Imam Bukhari ini dapat dinilai shahih (Saltanera, 2015).

\section{Syarah Hadis Keutamaan Air Wudu sebagai Kecantikan Wajah}

Berdasarkan dengan kajian hadis, syarah itu merupakan penjelasan atau pengungkapan makna yang terdapat pada suatu hadis (Muhtador, 2016). Melalui tahapan takhrij ini dapat diketahui bahwa suatu hadis dapat diamalkan (ma'mul) apabila hadis tersebut diterima (maqbul) (Darmalaksana, 2021). Seperti yang telah dipaparkan sebelumnya, bahwa hadis riwayat al-Bukhari No. 133 ini dapat dinilai shahih. Hadis riwayat alBukhari No. 133 menjelaskan bahwa pada hari kiamat nanti umat Rasulullah Saw. akan dihadirkan dengan wajah yang berseri-seri karena sisa dari air wudu. Maka bagi yang mampu mempertahankan wudunya maka itu sangat baik untuk dilakukan (Saltanera, 2015).

Wudu merupakan aktivitas mengusap, membasuh, menyela-nyela anggota tubuh seperti wajah, tangan, kepala, telinga, dan kaki dengan menggunakan air yang suci dan bersih (Rokhman, 2008). Wudu itu suatu ibadah, jika dapat dilakukan dengan benar maka akan memperoleh keutamaan atau manfaat yang luar biasa, baik dari segi lahiriah maupun batiniah (Syahputra, 2020). Melaksanakan wudu harus sesuai syariat yang telah ditentukan mulai dari rukun wudu, syarat wudu, dan sunnahsunnah wudu agar manfaat atau keutamaannya dapat dirasakan secara sempurna. Seperti yang tertera pada hadis di atas bahwa keutamaan dari wudu yaitu pada hari kiamat nanti akan bercahaya anggota wudu orang yang berwudu serta menjadi pembeda umat Nabi Muhammad Saw. dengan umat lainnya dengan tampaknya cahaya pada anggota wudu (Hidayati, 2008). Cahaya itu juga merupakan perhiasan bagi seorang mukmin karena bekas wudunya (Amaliah, 2020). Selain itu, basuhan air wudu yang diusapkan pada wajah dapat menyegarkan kulit wajah dan menjadikan mata kita lebih fresh serta tidak terasa lelah (Afif, Muhammad \& Khasanah, 2018; Syahputra, 2020). Salah satu bentuk ibadah kepada Allah Swt, sebagai seorang muslim dan muslimah kita dianjurkan untuk senantiasa menjaga wudu dan juga sebagai bentuk upaya menjaga kebersihan wajah (Amaliah, 2020). Jika wajah sudah bersih, maka akan tampaklah sinar-sinar cahaya dari wajah kita sebagai kecantikan yang alami. Wajah orang yang berwudu itu akan tampak lebih awet muda walaupun sudah tua. Hal ini dikarenakan ketika berwudu itu dibasuh sebanyak tiga kali. Wajah yang dibasuh oleh air wudu sebanyak tiga kali akan terbebas dari segala kotoran serta kelenturan kulit wajahnya dapat terjaga (Zulfa, 2019).

Menggunakan air yang suci dan mensucikan itu sangat dibutuhkan sebagai sarana dalam berwudu. Air yang sifatnya bersih, sejuk, dan syifa' (terapis) ini juga sangat banyak kegunaannya serta dapat dijadikan sarana 
Jurnal Riset Agama, Volume 1, Nomor 2 (Agustus 2021): 458-469

Zhafirah Najla/Keutamaan Air Wudu sebagai Kecantikan Wajah: Studi Takhrij dan Syarah Hadis

pengobatan (Amaliah, 2020). Oleh karena itu, setelah mengetahui keutamaan luar biasa dari berwudu, bagi seseorang yang ingin menjaga kecantikan wajahnya secara alami maka tanpa harus bersusah payah lagi mencari dan membeli produk kecantikan yang tepat bagi wajah. Dengan wudu yang terbilang sederhana ini dapat dijadikan solusi untuk menjaga kecantikan wajah serta dapat pula menjaga kesucian diri karena berkat wudunya Allah Swt. melimpahi cahaya rahmat dan kebaikan (Zulfa, 2019).

\section{Kesimpulan}

Wudu merupakan serangkaian aktivitas yang biasa dilakukan ketika hendak melaksanakan salat, tetapi pelaksanaannya tidak membatasi hanya untuk itu. Bahkan wudu memiliki keutamaan yang luar biasa. Hal ini juga dapat menjadikan orang-orang lebih semangat lagi untuk menjaga wudu. Selain melaksanakannya bernilai ibadah, wudu ternyata dapat memancarkan cahaya kecantikan tersendiri dari wajah dan cahaya kecantikannya lebih alami serta bertahan lama. Seperti pada hadis Imam al-Bukhari No. 133 yang telah dipaparkan di atas, bahwa hadis tersebut dinilai shahih baik sanad maupun matan, meskipun terdapat catatan satu orang rawi yang dinilai dhaif oleh an-Nasa'i yaitu Yahya bin 'Abdullah bin Bukair, namun riwayatnya tetap diterima karena oleh para ulama lain juga banyak yang menilai bahwa rawi tersebut tsiqah. Kehujjahan hadis Imam al-Bukhari ini dapat dijadikan pengamalan dalam kehidupan sehari-hari. Pemaknaan hadis menunjukkan bahwa pada hari kiamat nanti umat Rasulullah Saw. akan dihadirkan dengan wajah yang berseri-seri karena sisa dari air wudu. Seseorang yang ingin menjaga kecantikan wajahnya secara alami maka tanpa harus bersusah payah lagi mencari dan membeli produk kecantikan yang tepat bagi wajah. Bahkan kebersihan, kesucian, dan kecantikan dapat terjaga dengan melaksanakan wudu sungguh-sungguh. Penelitian ini masih memerlukan penelitian yang lebih lanjut dan mendalam dari bidang ilmu fiqih karena keterbatasan penulis yang hanya menyajikan takhrij dan syarah hadis secara singkat. Penelitian ini juga diharapkan dapat memberikan manfaat terkhusus bagi kaum perempuan.

\section{Daftar Pustaka}

Afif, Muhammad \& Khasanah, U. (2018). Urgensi Wudhu dan Relevansinya bagi Kesehatan (Kajian Ma'anil Hadits ) dalam Perspektif Imam Musbikin. Riwayah: Jurnal Studi Hadis, 3(2), 215-230.

Amaliah, S. H. R. (2020). Pengaruh Intensitas Berwudu terhadap Kejadian Akne Vulgaris pada Mahasiswa Ma'had al-Birr Universitas Muhammadiyah Makassar. Universitas Muhammadiyah Makassar.

Asmidar, A. (2018). Hukum Wudu bagi Pengguna Kosmetik Water Proof 
Jurnal Riset Agama, Volume 1, Nomor 2 (Agustus 2021): 458-469

Zhafirah Najla/Keutamaan Air Wudu sebagai Kecantikan Wajah: Studi Takhrij dan Syarah Hadis

Menurut MUI (Majelis Ulama Indonesia) Kota Medan. Universitas Islam Negeri Sumatera Utara.

Darmalaksana, W. (2018). Paradigma Pemikiran Hadis. JAQFI: Jurnal Aqidah Dan Filsafat Islam, 2(1), 95-106.

Darmalaksana, W. (2020a). Formula Penelitian Pengalaman Kelas Menulis. Jurnal Kelas Menulis UIN Sunan Gunung Djati Bandung. http://digilib.uinsgd.ac.id/32620/

Darmalaksana, W. (2020b). Metode Penelitian Kualitatif Studi Pustaka dan Studi Lapangan. Pre-Print Digital Library UIN Sunan Gunung Djati Bandung.

Darmalaksana, W. (2020c). Penelitian Hadis Metode Syarah Pendekatan Kontemporer: Sebuah Panduan Skripsi, Tesis, dan Disertasi. Diroyah: Jurnal Studi Ilmu Hadits, 1(5), 58-68.

Darmalaksana, W. (2020d). Prosiding Proses Bisnis Validitas Hadis untuk Perancangan Aplikasi Metode Tahrij. Jurnal Ushuluddin UIN Sunan Gunung Djati Bandung, 1, 1-7.

Darmalaksana, W. (2021). Kosmetik Halal sebagai Lifestyle untuk Kesehatan: Studi Takhrij Hadis dan Syarah Hadis. Pre-Print Kelas Menulis Sunan Gunung Djati Bandung, 148, 148-162.

Hidayati, M. S. (2008). Hadits tentang Anjuran Berwudhu dalam Melaksanakan Aktifitas Diluar Shalat: Telaah Ma'anil Hadits. UIN Walisongo.

Lela, \& L. (2015). "Ketenangan": Makna Dawamul Wudhu (Studi Fenomenologi Pada Mahasiswa UIN Raden Fatah Palembang). Psikis: Jurnal Psikologi Islami, 1(2), 55-66.

Marzuki, M. (2006). Kritik terhadap Kitab Shahih al-Bukhari dan Shahih Muslim. Humanika: Kajian Ilmiah Mata Kuliah Umum, 6(1), 26-38. https:/ / doi.org/10.21831/hum.v6i1.3809

Muhtador, M. (2016). Sejarah Perkembangan Metode dan Pendekatan Syarah Hadis. Riwayah: Jurnal Studi Hadits, 2(2), 259-272.

Nadhiran, H. (2014). Kritik Sanad Hadis: Telaah Metodologis. Jurnal Ilmu Agama: Mengkaji Doktrin, Pemikiran, Dan Fenomena, 15(1), 91-109.

Qomarullah, M. (2016). Metode Takhrij Hadits dalam Menakar Hadits Nabi. EL-Ghiroh: Jurnal Studi Keislaman, XI(02), 23.

Rokhman, K. (2008). Pengaruh Wudu dalam Mereduksi Marah. Universitas Islam Negeri Syarif Hidayatullah Jakarta.

Saltanera. (2015). Ensiklopedi Hadis Kitab 9 Imam. Lembaga Ilmu Dan Dakwah Publikasi Sarana Keagamaan, Lidwa Pustaka.

Syahputra, H. (2020). Ritual Wudhu: Upaya Menjaga Kesehatan Tubuh dengan Perawatan Spiritual. Al-Hikmah: Jurnal Theosofi Dan Peradaban Islam, 2(2). https://doi.org/10.51900/al-hikmah.v2i2.8801

Umbarani, E. M., \& Fakhruddin, A. (2021). Konsep Mempercantik Diri dalam Prespektif Islam dan Sains. Jurnal Dinamika Sosial Budaya, 23(1), 115-125. 
Jurnal Riset Agama, Volume 1, Nomor 2 (Agustus 2021): 458-469

Zhafirah Najla/Keutamaan Air Wudu sebagai Kecantikan Wajah: Studi Takhrij dan Syarah Hadis

Wiharsari, J. C. (2019). Konsep Kecantikan dan Pemanfaatan Produk Kosmetik Wajah pada Mahasiswi Surabaya. Universitas Airlangga.

Zulfa, F. F. (2019). Manfaat Wudu terhadap Kesehatan dari Perspektif Hadis Nabi Saw. UIN Alauddin Makassar. 